\title{
Sixteen years of simulated summer and winter warming have contrasting effects on soil mite communities in a sub-Arctic peat bog
}

\author{
Inkeri Markkula ${ }^{1}$ (D) J. Hans C. Cornelissen ${ }^{2} \cdot{\text { Rien } \text { Aerts }^{2}}^{2}$
}

Received: 5 June 2018 / Revised: 18 December 2018 / Accepted: 19 December 2018 / Published online: 29 December 2018

(c) The Author(s) 2018

\begin{abstract}
Northern peatlands are very sensitive to changes in climate. Impacts of increased temperatures on hydrology, vegetation structure and soil carbon are already well documented from northern peatlands. In contrast, effects of global warming on soil mites, and seasonal effects in particular, have received less attention, even though soil mites are an important component in ecosystems as they contribute to nutrient dynamics and decomposition. We investigated the impacts of long-term (16 years) experimental seasonal climate manipulations (summer warming, winter warming with snow accumulation, and year-round warming) on oribatid (Oribatida) and mesostigmatid (Mesostigmata) mite communities in a peat bog underlain by discontinuous permafrost, in Abisko, Northern Sweden. We found that (1) Year-round warming treatment had neither impact on life-history trait compositions nor on total abundances of oribatid mites, possibly because of opposite effects of summer and winter warming; (2) Small-bodied oribatid mites, in particular those belonging to genera Suctobelba, increased in abundance under the summer warming treatment; (3) The species richness of oribatid mites was negative affected by yearround warming; (4) Mesostigmatid mites, which were not identified to species level, were found to decrease in abundance under year-round warming. Because different mite taxa with different body sizes and diets play distinct roles in carbon and nutrient dynamics, the observed changes in mite communities may impact ecosystem functions in northern peatlands.
\end{abstract}

Keywords Global warming $\cdot$ Oribatid mites $\cdot$ Mesostigmatid mites $\cdot$ Peatlands $\cdot$ Ecological traits $\cdot$ Life-history traits

\section{Introduction}

Global mean temperatures have increased during the twentieth century and still continue to do so. The global mean annual temperatures have increased by $0.85{ }^{\circ} \mathrm{C}$, over the period from 1880 to 2012 (IPCC 2014), and in the Arctic region, temperatures have been increasing at a rate roughly twice that observed at lower latitudes (Blunden and Arndt 2013). Northern peatlands are very sensitive to climate warming (Luoto et al. 2004). Globally, peatlands cover an

Electronic supplementary material The online version of this article (https://doi.org/10.1007/s00300-018-02454-4) contains supplementary material, which is available to authorized users.

Inkeri Markkula

inkeri.markkula@utu.fi

1 Biodiversity Unit, Department of Biology, University of Turku, 20014 Turku, Finland

2 Systems Ecology, Department of Ecological Science, Faculty of Science, Vrije Universiteit Amsterdam, De Boelelaan 1085, $1081 \mathrm{HV}$ Amsterdam, Netherlands estimated area of 400 million ha, of which most, circa 350 million ha, are found in the Northern hemisphere (Strack 2008). Northern peatlands store one-third of all carbon on Earth, more than any other terrestrial ecosystem (Davidson and Janssens 2006; Dise 2009), and are important ecosystems for many species of birds, plants and invertebrates (Luoto et al. 2004), many of which are important contributors to carbon sequestration or release (Laakso and Setälä 1999; Filser 2002; Heijmans et al.2008). Therefore, it is particularly important to study the impacts of climate warming on northern peatland ecosystems. Direct and indirect effects of warming on e.g. plant growth and phenology, vegetation structure, permafrost and hydrological conditions are well documented in northern peatlands (e.g. Aerts et al. 2004, 2009; Dorrepaal et al. 2004, 2006, 2009; Keuper et al. 2011, 2012; Bosiö et al. 2012; O'Donnell et al. 2012; Treat et al. 2016; Gałka et al. 2017), and some studies also document the effects of warming on belowground organisms, such as testate amoebae, Collembola and soil mites (Tsyganov et al. 2012; Krab et al. 2013; Alatalo et al. 2017). Soil mites are important contributors to decomposition processes and 
nutrient cycling in the soil, through feeding on microorganisms, and by affecting the dispersal of microbial fungi (Moore et al. 1988; Maraun et al. 1998; Renker et al. 2005; Lenoir et al. 2007) and litter chemistry (Wickings and Grandy 2011). Oribatid mites are one of the most diverse and numerous invertebrate groups in peatlands (Behan-Pelletier and Bissett 1994; Murvanidze and Kvavadze 2010), and in those high-latitude soil ecosystems where earthworms are absent or have low densities and species diversity, their functional role, together with springtails (Collembola), enchytraeids (Enchytraeidae) and nematodes (Nematoda), is particularly important (Ruess et al. 1999).

The past decade has seen a shift from a merely taxonomic approach to assessment of ecological and life-history traits of invertebrates in response to environmental change. Functional, ecological and life-history traits are thought to be sensitive indicators of community change, and can reveal mechanisms behind the response of species to environmental manipulations (e.g. McGill et al. 2006; Makkonen et al. 2011; Farska et al. 2014a). The approach is also increasingly used to explain the responses of microinvertebrates to environmental change, for example, the responses of Collembola to simulated warming in the sub-Arctic (Makkonen et al. 2011), the impacts of natural disturbance and management intensity on forest microarthropods (Farska et al. 2014a, b) and effects of climate change on microarthropod communities in boreal forests (Lindo et al. 2012).

Previous studies have reported that oribatid mite communities are resistant to experimental warming (Hodkinson et al. 1996; Hågvar and Klanderud 2009; Alatalo et al. 2017), and well adapted to annual changes in temperature and moisture (Convey 1996; Coulson et al. 1996). However, their responses to simulated warming are also found to be habitat-specific (Sjursen et al. 2005a). Moreover, previous research suggests that oribatid mites may benefit from earlier snow melt and longer growing season associated with warming (Dollery et al. 2006), but also from lower winter soil temperatures (Sjursen et al. 2005b). For mesostigmatid mites, neutral, positive and negative responses to simulated warming have all been reported (Sjursen et al. 2005a; Wu et al. 2014).

Several studies have shown that increased temperature can have impacts on the relative proportions of fungi and bacteria in soil (Blankinship et al. 2011; Garcia-Palacios et al. 2015; Asemaninejad et al. 2018), which may affect fungal-feeding oribatid mites. Also, shifts in feeding modes in oribatid mite communities as a response to disturbance have been previously reported (Farska et al. 2014a, b). Previous study also suggests that responses of oribatid mites to experimental warming are size dependent and that smallbodied oribatid mites benefit from soil warming (Lindo 2015). Small-bodied oribatid mites usually have parthenogenetic reproductive mode, but whether parthenogenetic species in particular are favoured by climate warming is not known (Lindo 2015).

One important aspect of climate warming in northern peatlands, not covered by previous studies, concerns the fact that climate warming itself, and its effects on organisms, may manifest itself differently in different seasons of the year. Seasonality of climate warming effects may be important for soil-dwelling organisms, which have to cope with annual cycles of great environmental variability from season to season, i.e. from frozen soil in winter, to very wet but cold soil around snow melt in spring, to warmer and drier soil in summer, and back to frozen soil in winter. To fill this knowledge gap, we investigated the impacts of long-term (16 years) climate manipulation on mite communities in a peat bog underlain by discontinuous permafrost, in Abisko, Northern Sweden. Specifically, we studied the impacts of experimental climate warming in different seasons (summer warming, winter warming with snow addition and yearround warming) on (1) species diversity; (2) densities; (3) community composition and (4) composition of ecological and life-history traits of oribatid mites. Three traits were chosen for analyses: reproductive mode, size and feeding guild. Also, the impacts of climate manipulations on overall densities of mesostigmatid mites, which were not identified to species level, were investigated.

We hypothesised that the overall abundance and species richness of Oribatida will not be significantly affected by modest $\left(0.5-2.8{ }^{\circ} \mathrm{C}\right)$ changes in annual temperature. However, based on earlier findings on that oribatid mites may be favoured by longer growing season, but also by lower soil temperature in winter, we expected the responses to be different under summer and winter climate manipulations. We also expected that the species responses will depend on their body size and feeding mode, and as a result, trait composition of oribatid mite communities will be altered by warming.

\section{Methods}

\section{Study area and experimental design}

The study was conducted in a sub-Arctic peat bog situated at the southern shore of Lake Torneträsk in Abisko, Sweden $\left(68^{\circ} 21^{\prime} \mathrm{N}, 18^{\circ} 49^{\prime} \mathrm{E}\right.$; Fig. 1$)$. The research site is situated on a north-facing gentle slope, and the bog is underlain by discontinuous permafrost. Vegetation in the bog is dominated by a continuous Sphagnum fuscum Schimper layer, and other bryophytes and lichens are abundant (Lang et al. 2009) but low in biomass. The low and open vascular plant community consists of Empetrum hermaphroditum Hagerup, Rubus chamaemorus L., Andromeda polifolia L., Betula nana L., 


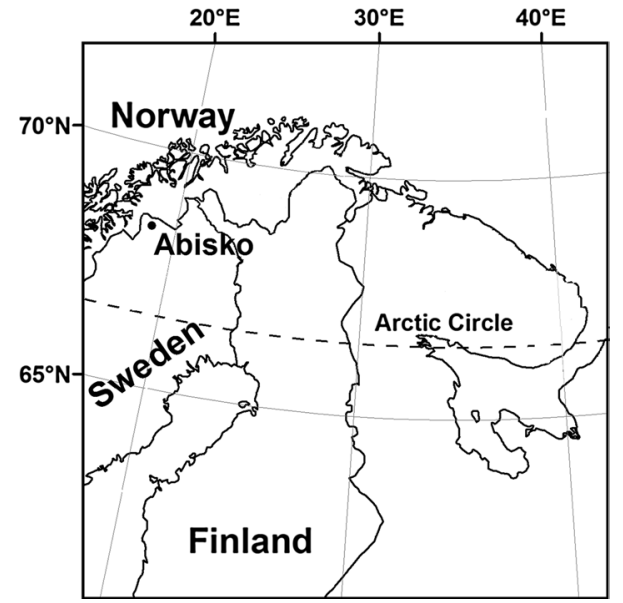

Fig. 1 Location of Abisko

Table 1 Climate treatments

\begin{tabular}{lllll}
\hline Number & Treatment & Summer & Winter & Spring \\
\hline 1 & Control & C & C & C \\
2 & Summer warming & W & C & C \\
3 & Winter warming + & C & S & W \\
4 & snow accumulation & & & \\
& Year-round warming & W & S & W \\
\hline
\end{tabular}

$C$ Control, $W$ warming, $S$ snow accumulation

Calamagrostis lapponica Wahlenb. and Vaccinium uliginosum $\mathrm{L}$.

The climate manipulation experiment was established in June 2000, when six different treatments simulating possible future climate scenarios were established (see: Aerts et al. 2004; Dorrepaal et al. 2004). The treatments are largely based on the scenarios of IPCC on that climate change is likely to cause higher summer, spring and winter temperatures and increase in winter precipitation during the twenty-first century (IPCC 2007; 2014). In this study, the experimental set up consisted of three climate change manipulations and a control treatment. The climate manipulations consist of summer warming (June-September), winter warming (October-late May) with snow accumulation, and year-round warming (Table 1). Each treatment was replicated five times, thus the total number of sampling plots was 20. Summer and winter treatments were chosen in order to test whether climate change manipulations during growing season (June-September), and outside the main growing season (October-late May) have different effects on soil mite communities. The effects of increased winter precipitation are of particular interest, because previous studies suggest that enhanced winter snow cover, resulting to higher temperatures under the snow and earlier soil thawing in spring, can lead to higher decomposition and nutrient mineralization rates in the soil (Aerts et al. 2012), which may result from, or lead to, changes in mite communities.

In the treatments, climate change manipulations were imposed by passive warming using a modified, larger version of the ITEX-open-top chambers (OTCs; see Marion et al. 1997). OTCs were hexagonal and $50 \mathrm{~cm}$ high, with a diameter of $1.6-1.8 \mathrm{~m}$ at the top and $2.2-2.5 \mathrm{~m}$ at the base. OTCs were made of transparent polycarbonate (Makro Life, Arlaplast, Sweden). The OTC's raise air temperatures at approximately $5 \mathrm{~cm}$ above the soil by $0.5-2.8{ }^{\circ} \mathrm{C}$ in winter, $0.7-1.2{ }^{\circ} \mathrm{C}$ in spring and by $0.9^{\circ} \mathrm{C}$ in summer. The soil temperatures were raised in spring by about $1{ }^{\circ} \mathrm{C}$, in summer by $0.6-0.9^{\circ} \mathrm{C}$ and in winter by $0.5-2.2{ }^{\circ} \mathrm{C}$ (Aerts et al. 2009). No indications of effects of the treatments on soil moisture were found (Aerts et al. 2009). Increased winter snow accumulation was accomplished as the OTCs serve as passive snow traps, when strong winds blow snow into them at the exposed site. Snow depths were measured until 2013 and during this time winter treatment increased the snow thickness by two-or threefold. During December-January (2012-2013), the average snow depths were $7.9 \mathrm{~cm}$ in control and $25.5 \mathrm{~cm}$ in winter warming treatment. During February-April, the snow depths were 15.7 and $30.5 \mathrm{~cm}$, respectively.

The control treatment (1) never had any OTC. The summer warming treatments (2) started in early or mid-June when the OTCs were placed over the vegetation. At the end of each growing season, OTCs were taken out from summer treatment plots and placed onto winter treatment plots. The year-round warming treatment (4) had OTCs continuously. For more detailed information regarding the experiment, see Aerts et al. (2004) and Dorrepaal et al. (2004, 2009).

\section{Sampling and identification of mites}

Sampling was conducted on the 6th of July 2016 by using a small soil corer of $5 \mathrm{~cm}$ diameter. Samples were taken from a Sphagnum-dominated part in each replicate plot of 4 treatments, 20 samples in total. One sample consisted of two soil cores (sample area $39.28 \mathrm{~cm}^{2}$ ), taken until approximately $6 \mathrm{~cm}$ depth. Samples were transported in a cool-box to the University of Turku, Finland, where extraction with Tullgren-Berlese-type funnels (Berlese 1905; Tullgren 1918) was started within $48 \mathrm{~h}$ from sampling. Funnels were run for 5 days, until all samples were dry. Extracted soil mites were stored in $75 \%$ ethanol. The numbers of oribatid and mesostigmatid mites were counted from the samples, and oribatid mites were identified to species or genera level by using light microscopy. Weigmann (2006) was used as identification guide and for nomenclature. Identified material is stored at the Zoological Museum of the University of Turku. 


\section{Data analyses}

To compare Oribatida species richness and diversity between treatments, Shannon biodiversity indices were calculated. Differences in biodiversity indices, mean number of Oribatida taxa and differences in Mesostigmata densities between treatments were tested using Analyses of Variance (ANOVA) with Dunn's post hoc tests. The homogeneity of variances was tested prior to analyses, and the data on Mesostigmata densities were log-transformed to meet the normality assumptions. Because for the oribatid mite species data, the parameters of normality could not be reached even after data transformations, differences in total density and densities of Oribatida species/genera between treatments were tested with Proc Glimmix procedure using negative binomial distribution. Tukey-Kramer test for multiple pair comparisons was performed as post hoc test. Differences in abundances were not tested for the species with very low abundance $(<6$ individuals found or species appearing only in one sample).

To illustrate the differences/similarities in Oribatida community composition between treatments, Nonmetric multidimensional scaling (NMDS) with Bray-Curtis dissimilarity index was conducted. For the trait analyses, we chose three life-history and ecological traits: feeding guild, reproductive mode and body size (Table 2; additional data are given in Online resource 1). Information regarding feeding guild and reproductive mode was gained from the following sources: Behan and Behan (1978), Bluhm et al. (2016), Díaz-Aguilar and Quideau (2013), Erdmann et al. (2007), Farska et al. (2014a, b), Fischer et al. (2010, 2014), Palmer and Norton (1991), Scheu and Maraun (2015) and Smelansky (2006). Information regarding body size was taken from Weigmann (2006), and the maximum values of the body size range were used. Even though these literature-based data can only broadly represent the high end of the species' body size range in the experiment, the assumption is that they should have broadly similar ranking across species.

To study the effects of warming treatments on trait compositions of oribatid mite communities, differences

Table 2 Description of Oribatida traits

\begin{tabular}{lll}
\hline Traits & Data type & Attribute \\
\hline Body size & Quantitative & In mm \\
Feeding guild & Ordinal & $1=$ fungi and animals \\
& & $2=$ predominantly \\
& & fungi, in part litter \\
& & $3=$ predominantly litter \\
& & $4=$ algae and lichen \\
Reproduction mode & Binary & $1=$ parthenogenetic \\
& & $2=$ sexual \\
\hline
\end{tabular}

in mean trait values $(N=5)$ between treatments were tested with ANOVA and Dunn's post hoc test. Prior to analyses, Community-Weighted Mean (CWM) values were calculated as

$\mathrm{CWM}=\sum_{i} p_{i} X_{i}$,

where $\mathrm{x}$ is the trait value of the $i$-th species, and $p$ is the relative abundance of the $i$-th species (see: Garnier et al. 2004).

Analyses were conducted with SAS version 6.1 and PAST-programme version 3.0.

\section{Results}

\section{Soil mite abundance and species diversity}

In total, 2401 specimens of Oribatida were identified from the samples, so on average 120 per plot sample, belonging to 19 species and 18 genera. The total number mesostigmatid mites found was 423 .

Mean density of oribatid mites varied significantly among summer and winter treatments and was highest in the summer warming treatment plots and lowest in the winter warming treatment plots, being $50 \%$ lower in the latter (Table 3). Mean densities of oribatid genus Suctobelba were $65 \%$ higher in summer warming treatment plots compared to control (Tukey-Kramer post hoc test, $p=0.028$ ) and $70 \%$ higher compared to winter warming with snow accumulation treatments (Tukey-Kramer post hoc test, $p=0.015$; Table 3). Melanozetes mollicomus was most abundant in summer warming treatment, and its mean densities were $91 \%$ higher in relation to year-round warming treatment plots (Tukey-Kramer post hoc test, $p=0.022$; Table 3). Mean densities of Nothrus pratensis were 76\% higher in summer (Tukey-Kramer post hoc test, $p=0.033$ ) and $73 \%$ higher in year-round warming treatment plots (Tukey-Kramer post hoc test, $p=0.019$ ) in comparison to winter warming plots (Table 3 ).

Abundances of Mesostigmata were highest in control plots, and lowest in year-round warming treatment plots. Year-round warming had a significant negative effect on the mean densities of Mesostigmata, which were $47 \%$ lower in relation to control (Dunn's post hoc test, $p=0.007$; Table 3).

Oribatida species richness (number of taxa) was highest in control plots, and significantly higher in comparison to year-round warming treatments (Dunn's post hoc test, $p=0.039$; Table 3). No significant differences were found in Shannon's $H$ and evenness indices between the treatments (Table 3). 
Table 3 Mean abundance of soil mites, 1000 individuals $/ \mathrm{m}^{2} \pm \mathrm{SE}$, in experimental plots, diversity indices, number of taxa and significant results of post hoc tests of multiple comparisons between treatments $(p \leq 0.05 ; N=5)$

\begin{tabular}{|c|c|c|c|c|c|c|}
\hline \multirow[t]{3}{*}{ Soil mite community } & \multicolumn{4}{|l|}{ Treatment } & \multirow{3}{*}{$\begin{array}{l}\text { Post hoc test } \\
\text { Significant } \\
\text { Comparisons }\end{array}$} & \multirow[t]{3}{*}{$p$} \\
\hline & Control & Summer & Winter & Year-round & & \\
\hline & & & & & & \\
\hline Total Mesostigmata & $7.89 \pm 1.34$ & $5.81 \pm 0.87$ & $6.31 \pm 0.90$ & $4.20 \pm 2.10$ & Control versus Year-round & 0.007 \\
\hline Total Oribatida & $20.17 \pm 5.15$ & $35.64 \pm 6.10$ & $17.47 \pm 3.85$ & $24.4 \pm 5.84$ & Summer versus Winter & 0.03 \\
\hline Oppiella nova (Oudemans 1902) & $6.57 \pm 2.56$ & $11.51 \pm 3.14$ & $6.47 \pm 2.79$ & $8.36 \pm 2.02$ & None & \\
\hline Multioppia glabra (Mihelcic 1955) & $2.65 \pm 1.01$ & $4.99 \pm 1.03$ & $3.36 \pm 1.17$ & $5.74 \pm 2.54$ & None & \\
\hline Oppiella translamellata (Willmann 1923) & $2.95 \pm 1.27$ & $5.75 \pm 2.88$ & $1.53 \pm 0.46$ & $2.63 \pm 0.94$ & None & \\
\hline Nothrus pratensis (Sellnick 1920) & $2.14 \pm 0.87$ & $3.46 \pm 2.16$ & $0.92 \pm 0.24$ & $3.87 \pm 1.28$ & $\begin{array}{l}\text { Summer versus Winter; } \\
\text { Year-round versus Winter }\end{array}$ & $\begin{array}{l}0.03 \\
0.002\end{array}$ \\
\hline Suctobelba spp. & $1.43 \pm 0.32$ & $4.12 \pm 1.61$ & $1.22 \pm 0.54$ & $1.63 \pm 0.48$ & $\begin{array}{l}\text { Summer versus Winter; } \\
\text { Summer versus Control }\end{array}$ & $\begin{array}{l}0.002 \\
0.03\end{array}$ \\
\hline Tectocepheus velatus (Michael 1880) & $1.78 \pm 0.96$ & $1.58 \pm 1.33$ & $1.17 \pm 0.66$ & $0.47 \pm 0.21$ & None & \\
\hline Melanozetes mollicomus (Koch 1902) & $0.36 \pm 0.10$ & $1.12 \pm 0.19$ & $0.41 \pm 0.29$ & $0.10 \pm 0.06$ & Summer versus Year-round & 0.02 \\
\hline Ceratozetes thienemanni (Willmann 1943) & $0.10 \pm 0.10$ & $1.27 \pm 1.03$ & 0 & 0 & None & \\
\hline C. Sellnicki (Rajski 1951) & 0 & $0.46 \pm 0.46$ & $0.31 \pm 0.20$ & $0.15 \pm 0.15$ & None & \\
\hline Damaeus auritus (Koch 1835) & $0.05 \pm 0.05$ & $0.10 \pm 0.06$ & $0.46 \pm 0.35$ & $0.05 \pm 0.05$ & None & \\
\hline Diapterobates humeralis (Hermann 1804) & $0.15 \pm 0.10$ & $0.10 \pm 0.10$ & $0.10 \pm 0.10$ & $0.05 \pm 0.05$ & None & \\
\hline Melanozetes meridianus (Sellnick 1928) & $0.36 \pm 0.36$ & 0 & 0 & 0 & None & \\
\hline Scheloribates initialis (Berlese 1908) & $0.25 \pm 0.20$ & 0 & $0.05 \pm 0.05$ & 0 & None & \\
\hline Carabodes subarcticus (Trägardh 1902) & $0.10 \pm 0.09$ & 0 & $0.10 \pm 0.10$ & 0 & - & - \\
\hline Heminothrus longisetosus (Willmann 1925) & 0 & 0 & 0 & $0.20 \pm 0.12$ & - & - \\
\hline Camisia biurus (Koch 1839) & 0 & $0.05 \pm 0.05$ & 0 & $0.10 \pm 0.10$ & - & - \\
\hline Platynothrus peltifer (Koch 1839) & $0.15 \pm 0.05$ & 0 & 0 & 0 & - & - \\
\hline Eupelops sp. & $0.05 \pm 0.05$ & $0.05 \pm 0.05$ & 0 & 0 & - & - \\
\hline Phthiracarus sp. & 0 & $0.05 \pm 0.05$ & $0.05 \pm 0.05$ & 0 & - & - \\
\hline Porobelba spinosa (Sellnick 1920) & 0 & 0 & $0.05 \pm 0.05$ & $0.05 \pm 0.05$ & - & - \\
\hline Chamobates borealis (Trägardh 1902) & 0 & $0.05 \pm 0.05$ & 0 & 0 & - & - \\
\hline Eupelops acromios (Hermann 1804) & 0 & 0 & 0 & $0.05 \pm 0.05$ & - & - \\
\hline No Oribatida Taxa & $10.8 \pm 0.20$ & $9.4 \pm 0.98$ & $9.2 \pm 0.86$ & $8.8 \pm 0.86$ & Control versus Year-round & 0.04 \\
\hline Shannon's $H$ & $1.92 \pm 0.11$ & $1.64 \pm 0.11$ & $1.73 \pm 0.14$ & $1.68 \pm 0.09$ & None & \\
\hline Evennes & $0.64 \pm 0.06$ & $0.57 \pm 0.05$ & $0.64 \pm 0.07$ & $0.63 \pm 0.03$ & None & \\
\hline
\end{tabular}

\section{Species and traits composition of oribatid mite communities}

The relative dominance structure of the Oribatida communities was similar between experiments, Oppiella nova, $O$. translamellata and Multioppia glabra being the dominant species in all treatments (Fig. 2). Warming treatments had no significant effect on ecological and life-history trait composition of oribatid mite communities (Table 4). Fungi- and animal-feeding, small-bodied (290-320 $\mu \mathrm{m})$ and parthenogenetic reproducing oribatid mites were dominant in all treatments, the relative mean abundance of those being highest in summer warming treatments (see: Online resource 2). As illustrated in NMDS configuration, there is no dissimilarity in oribatid mite communities which could be connected to warming treatments (Fig. 3). The stress value for the
Bray-Curtis dissimilarity is relatively high (0.16); however, as Clarke (1993) has noted, stress values under 0.2 can be used to produce usable NMDS configurations.

\section{Discussion}

\section{The effects of seasonal climate manipulations on oribatid mite communities}

In Arctic and sub-Arctic ecosystems, seasonality of climate warming effects may be important for soil-dwelling organisms, which have to cope with annual cycles of great environmental variability from season to season. As far as we know, our study is the first experimental study which covers the effects of seasonal climate manipulations on oribatid 


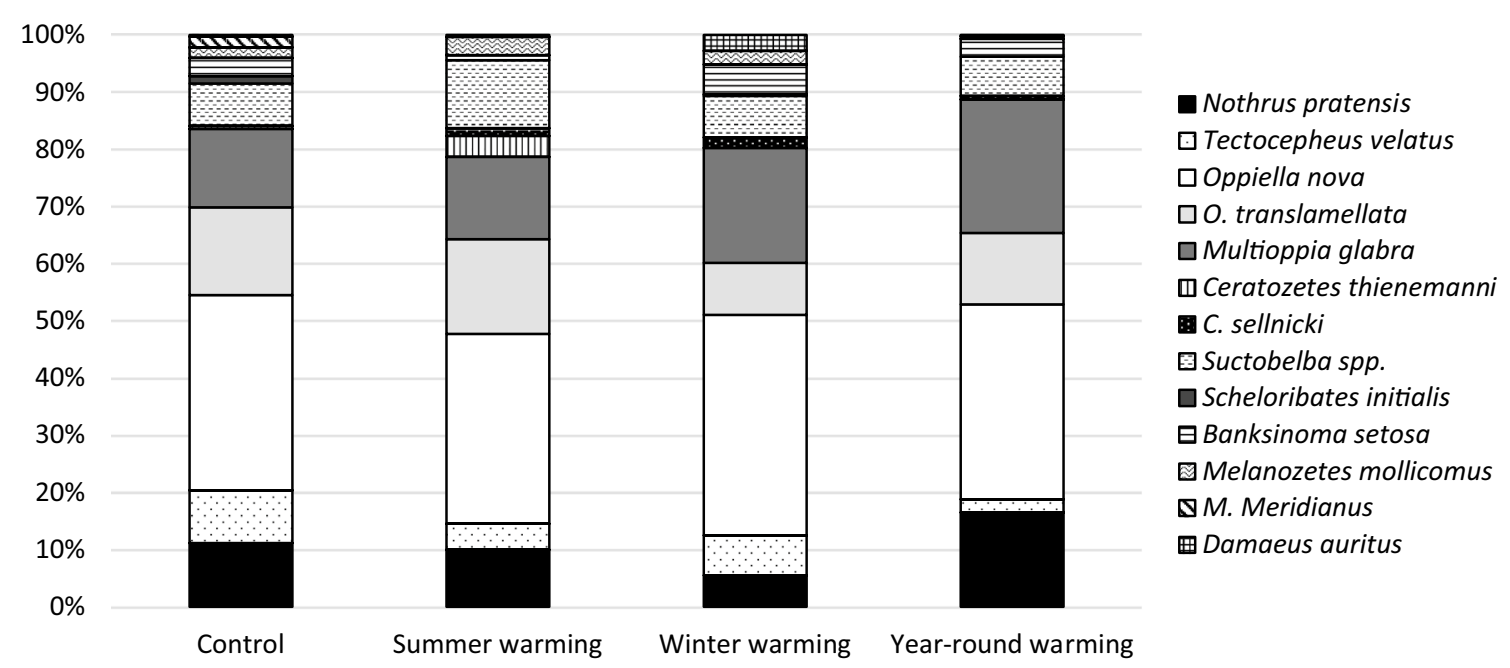

Fig. 2 Dominance structure of oribatid mite communities in treatments. Sample size $196.4 \mathrm{~cm}^{2}$

Table 4 ANOVA results for Oribatida traits compositions

\begin{tabular}{llll}
\hline Trait & \multicolumn{2}{l}{ ANOVA } & Tukey's pairwise \\
\cline { 2 - 3 } & $F$ & $p$ & Significant comparisons \\
\hline Size & 1.02 & 0.43 & None \\
Feeding guild & 1.36 & 0.32 & None \\
Reproductive mode & 0.87 & 0.47 & None \\
\hline
\end{tabular}

mite communities in northern peatlands. Our results suggest that the effects of warming on densities of oribatid mites are season specific in northern peatlands, and that the main impacts are connected to summer-time temperature increase. The effects of summer warming are, however, likely to be diminished by negative impacts of winter warming with snow accumulation. This finding of summer and winter warming with snow accumulation having contrasting effects on abundances of oribatid mites may partly explain why previous experimental studies conducted in the sub-Arctic and Arctic region have not found any impact of simulated year-round warming on them.

It should be, however, noted here that, as the sampling was conducted once in early July, observed changes in oribatid mite communities may partly derive from warming having variable impacts on phenology of different species. Soil mites exhibit seasonal variation in abundance, and warming probably affects their phenology (Alatalo et al. 2017). However, oribatid mites living in cold areas often have extended life cycles which may span over many years (Norton 1994; Coulson et al. 2000), and thus our results should reflect more general impacts of warming than just warming-induced earlier hatching of juveniles. However, repeated sampling in different times of summer would be good to find out how much of the observed changes are caused by the warminginduced alterations in mite phenology.

\section{Effects of warming on ecological and life-history trait compositions}

In our experiment, small-bodied oribatid mites increased in abundance under summer-time warming. We did not find field studies that investigated effects of seasonal warming for comparison, but in one peatland soil mesocosm experiment, short-term (1.5 years)-simulated warming increased the densities of small-bodied Oribatida, especially those belonging to the families Suctobelbidae and Brachychthoniidae (Lindo 2015). These findings are of interest as body size is a morphological trait that has been proposed as a "universal indicator" of an organism's ecological role (Petchey and Belgrano 2010). Moreover, Brown et al. (2004) have shown that the universal metabolic scaling rules dictate that small species are favoured by higher temperatures because small species have higher developmental rates and higher maximum rates of population growth than species of larger body size. Our results suggest, however, that the effects of warming on small-bodied oribatid mites are season dependent. The temperatures alone cannot explain the increase of densities of Suctobelba spp. as the OTC's raised soil temperatures more during winter (by $0.5-2.2^{\circ} \mathrm{C}$ ) than during summer (by $0.6-0.9^{\circ} \mathrm{C}$ ). One explanation could be that the peat surface layers, which can dry out on warm summer days, are protected by snow cover during winter. Small-bodied microarthropod species may be less sensitive to summer warming in peatlands because they can move deeper down into the soil when the surface peat warms up or dries out (see Krab et al. 2010). Also, oribatid mites that are 
Fig. 3 The Nonmetric multidimensional scaling ordination configuration based on the Oribatida species collected in treatment plots. $R^{2}$ values for axis 1: 0.66 and axis 2: 0.29. Stress: 0.16

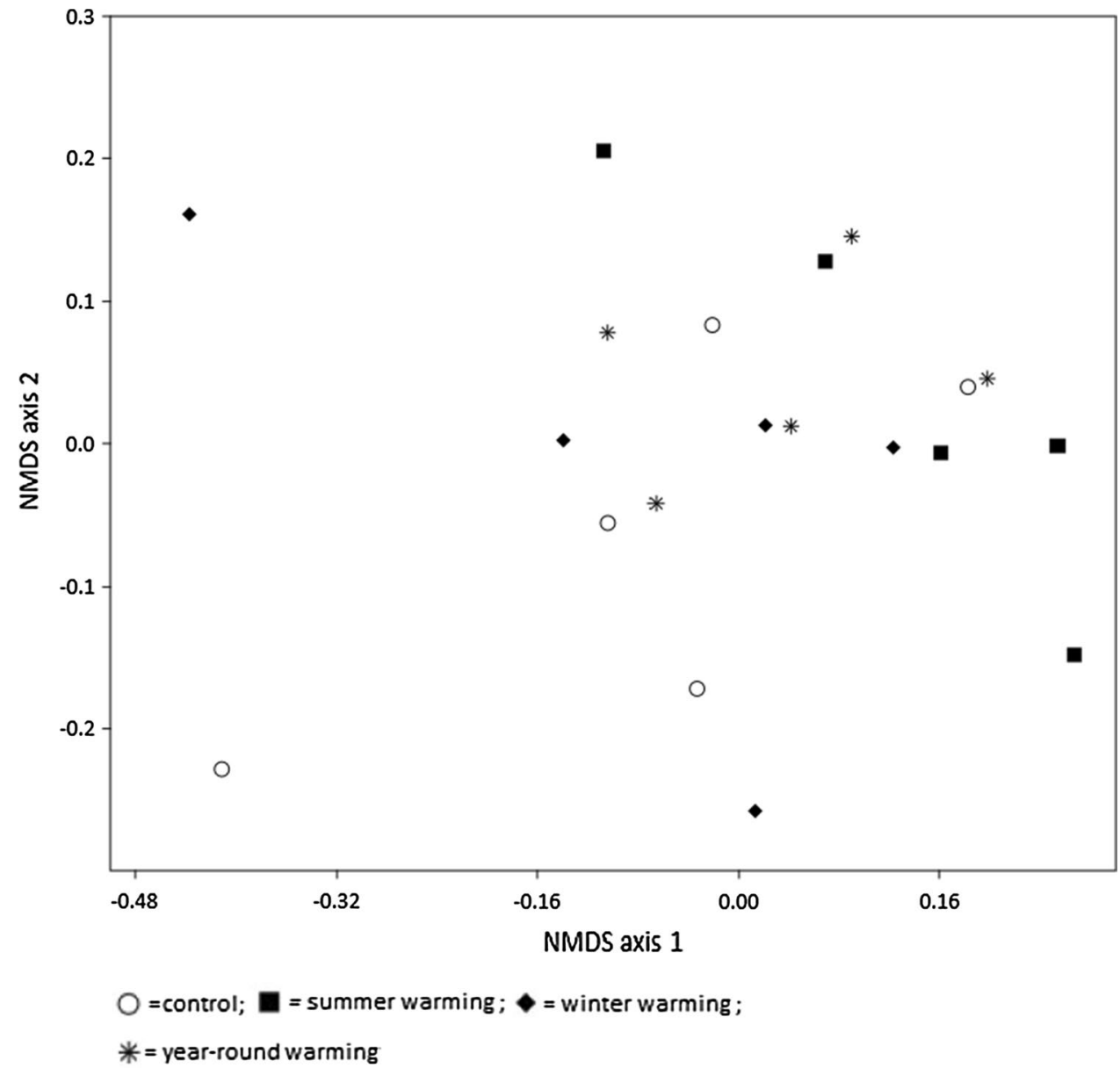

adapted to cold winters, may be more susceptible to wintertime temperature increase.

In contrast to our expectations, compositions of ecological and life-history traits in Oribatida communities were not affected by warming, and in line with that, neither were species compositions. Even though small-bodied oribatid mites increased in abundance under summer warming, this did not lead to changes in body size compositions in the communities. Small-bodied oribatid mites usually have parthenogenetic reproductive mode, but it is not known whether parthenogenetic species in particular are favoured by climate warming (Lindo 2015). In our study, the compositions of reproductive modes of oribatid mites were not affected by warming treatments, which could be due to high heterogeneity of life-history tactics within parthenogenetic oribatid mites: they can be fast reproducing and disturbance tolerant, or euedaphic (soil dwelling) and slowly developing (Maraun and Scheu 2000).

Based on previous studies reporting that increased temperatures affect the proportions of fungi and bacteria in soil (Blankinship et al. 2011; Garcia-Palacios et al. 2015; Asemaninejad et al. 2018), which may in turn affect microarthropods feeding on them, we expected changes in feeding guild compositions of oribatid mites to occur under warming treatments. Also, shifts in feeding guild composition in oribatid mite communities in response to disturbance have been previously reported (Farska et al. 2014a, b). Sjursen et al. (2005a) concluded in their study that observed changes in soil microarthropod communities under warming treatments are probably explained by changes in food availability rather than by direct climatic influences. Our results, however, did not support our expectations. This could be explained by the relatively high numbers of fungi- and animal-feeding species (Feeding Guild 1) in our study plots: 69-80\% of specimens recorded belonged to this group. Species belonging to this group can feed on a variety of food sources, including living and dead animals (nematodes, springtails) and fungi, and they have even been described as omnivorous (Schneider 2005). Therefore, species in this feeding guild may have a better capacity to adjust to changing conditions. Moreover, previous studies have shown that fungal-feeding (Guild 2) oribatid mites can be selective in feeding, but most of them feed on a wide spectrum of fungal species (Schneider et al. 2004). 


\section{Role of habitat moisture for mite responses to climate warming}

A recent study from Greenland reported that arthropod communities in drier habitats appear to be more sensitive to climate change effects than those in wet habitats (Koltz et al. 2018). The negative effects of experimental warming on soil microarthropods seem to be concomitant with those of decreases in soil moisture (Hodkinson et al. 1998; Kardol et al., 2011; Koltz et al. 2018), and it is well known that drought conditions impact soil microarthropods negatively (Blankinship et al. 2011; Lindo et al. 2012). However, in peatland systems, reductions in soil moisture can actually benefit soil microarthropods by increased habitable pore space and aerobic conditions (Turnbull and Lindo 2015), and there is also evidence that oribatid mite communities can be resistant to long-term experimental warming, irrespective of the effects of warming on soil moisture (Alatalo et al. 2017). Our results partly support the finding that wet habitat communities are resistant to warming effects.

\section{Ecosystem functions in peatlands under warming}

Year-round warming decreased the numbers of oribatid mite taxa in our climate manipulation experiment. This finding is important, as sub-Arctic ecosystems usually have low species diversity and thus the number of species is more critical to ecosystem functioning than in high-diversity systems (Heemsbergen et al. 2004; Roscher et al. 2004). This may be due to low functional redundancy in low-diversity systems, i.e. there are few species to take over functional roles when other species are lost. In other words, if the amount of primary productivity and the physio-chemical environment were held constant in all ecosystems, fewer species would contribute more to a particular ecosystem function (Wall 2007). Low-diversity systems are also thought to be more vulnerable to disturbance (Yachi and Loreau 1999), and to invasion of alien species (Nielsen et al. 2011). Therefore, through a decrease in species richness of Oribatida, climate warming may affect soil ecosystem functions, especially carbon and nutrient dynamics in Sphagnum-dominated peatlands. However, Nielsen et al. (2011) noted in their review, that even though there is theoretical evidence that species richness may be important for the stability of ecosystem functions, the few studies conducted on soil communities have reported mixed results with positive, neutral and negative relationships.

The overall consequences of warming on belowground ecosystem functions are still unclear. Lindo (2015) concluded that community downsizing in soil systems may lead to reductions in food web trophic transfer efficiency, as body size is intricately linked to metabolism, with consequences for nutrient and energy dynamics, and possibly to nutrient losses and decreased stability in belowground systems. In our experimental site, the numbers of small-bodied oribatid mites increased under summer-time warming in line with the increase in total abundance of oribatid mites, while the relative densities of small-bodied species did not change. Our results only partly support the theory of small species being favoured by higher temperatures (Brown et al. 2004) and suggest that the responses can vary depending on season.

We observed that the densities of mesostigmatid mites were significantly decreased by year-round warming, which together with the increase of small-bodied oribatid mites can possibly lead to changes in nutrient release. Staddon et al. (2010) reported reductions in both $\mathrm{C}$ and $\mathrm{N}$ release from a moss-mesocosm system after an increase in small-bodied microbial grazers, following the loss of large-bodied predators in a tropic cascade. However, the decreasing effects of warming on mesostigmatid mites were not consistent with the increase in small-bodied oribatid mites, which had the highest densities under the summer-time warming treatment. Yet, summer warming had no impact on mesostigmatid mites. There is evidence from laboratory experiments that predation of Mesostigmata strongly affects the species compositions of oribatid mites. Schneider and Maraun (2009) showed that species belonging to the families Oppiidae and Suctobelbidae decreased when predatory Mesostigmata were added to a mesocosm experiment, while the larger Oribatida species were more resistant to predation. Our results suggest that the changes in oribatid mite communities are not connected to densities of mesostigmatid mites; however, no further conclusions can be made because Mesostigmata were not identified to higher taxonomical level.

\section{Conclusions}

We found that the effects of climate warming on oribatid mite communities in a sub-Arctic peat bog were season specific. The results suggest that the impacts of climate warming on oribatid mite communities in northern peatlands are mostly connected to summer-time temperature increase, and partly support the theory of small species being favoured by higher temperatures, as small-bodied Suctobelba spp. increased in abundance under summer-time warming treatment. Year-round climate warming was found to have decreasing effect on species richness of oribatid mites and densities of mesostigmatid mites. Because different mite taxa with different body sizes and diets play different roles in carbon and nutrient dynamics, the observed changes in mite communities may impact ecosystem functions in northern peatlands.

Acknowledgements Open access funding provided by University of Turku (UTU) including Turku University Central Hospital. We are 
grateful to the staff of the Abisko Scientific Research Station and Richard Van Logtestijn for the maintenance of the experiment. Thanks to Ritva Penttinen for her help in oribatid mite identifications. This study was funded by Finnish Cultural Foundation Lapland Regional Fund.

\section{Compliance with ethical standards}

Conflict of interest The authors have no conflicts of interests to declare.

OpenAccess This article is distributed under the terms of the Creative Commons Attribution 4.0 International License (http://creativeco mmons.org/licenses/by/4.0/), which permits unrestricted use, distribution, and reproduction in any medium, provided you give appropriate credit to the original author(s) and the source, provide a link to the Creative Commons license, and indicate if changes were made.

\section{References}

Aerts R, Cornelissen JHC, Dorrepaal E, van Logtestijn RSP, Callaghan TV (2004) Effects of experimentally imposed climate scenarios on flowering phenology and flower production of subarctic bog species. Global Change Biol 10:1599-1609

Aerts R, Callaghan TV, Dorrepaal E, van Logtestijn RSP, Cornelissen JHC (2009) Seasonal climate manipulations result in speciesspecific changes in leaf nutrient levels and isotopic composition in a sub-arctic bog. Funct Ecol 23:680-688

Aerts R, Callaghan TV, Dorrepaal E, van Logtestijn RSP, Cornelissen JHC (2012) Seasonal climate manipulations have only minor effects on litter decomposition rates and $\mathrm{N}$ dynamics but strong effects on litter $\mathrm{P}$ dynamics of sub-arctic bog species. Oecologia 170:809-819

Alatalo JM, Jägerbrand A, Juhanson J, Michelsen A, Luptacik P (2017) Impacts of twenty years of experimental warming on soil carbon, nitrogen, moisture and soil mites across alpine/subarctic tundra communities. Sci Rep 7:44489. https://doi.org/10.1038/srep44489

Asemaninejad A, Thron RG, Branfireuna BA, Lindo Z (2018) Climate change favours specific fungal communities in boreal peatlands. Soil Biol Biochem 120:28-36

Behan VM, Behan SB (1978) Feeding habits and spore dispersal of Oribatid mites in the North American arctic. Rev Ecol Biol Sol 15:497-516

Behan-Pelletier VM, Bissett B (1994) Oribatida of Canadian peatlands. Mem Entomol Soc Can 169:73-88

Berlese A (1905) Apparecchio per raccogliere presto ed in gran numero piccoli Artropodi. Redia 2:85-90

Blankinship JC, Niklaus PA, Hungate BA (2011) A meta-analysis of responses of soil biota to global change. Oecologia 65:553-565

Bluhm C, Scheu S, Maraun M (2016) Temporal fluctuations in oribatid mites indicate that density-independent factors favour parthenogenetic reproduction. Exp Appl Acarol 68:387-407

Blunden J, Arndt DS (2013) State of the climate in 2012. Bull Am Meteorol Soc 94:S1-S238

Bosiö J, Johansson M, Callaghan TV, Johansen B, Christensen TR (2012) Future vegetation changes in thawing subarctic mires and implications for greenhouse gas exchange - a regional assessment. Clim Change 115:379-398

Brown JH, Gillooly JF, Allen AP, Savage VM, West GB (2004) Toward a metabolic theory of ecology. Ecology 85:1771-1789

Clarke KR (1993) Non-parametric multivariate analyses of changes in community structure. Aust J Ecol 18:117-143
Convey P (1996) Overwintering strategies of terrestrial invertebrates in Antarctica-the significance of flexibility in extremely seasonal environments. Eur J Entomol 93:489-506

Coulson SJ, Hodkinson ID, Wooley C, Webb NR, Block W, Worland MR, Strathdee JS (1996) Effects of experimental temperature elevation on high-arctic soil microarthropod populations. Polar Biol 16:147-153

Coulson SJ, Leinaas HP, Ims RA, Sovik G (2000) Experimental manipulation of the winter surface ice layer: the effects on a high Arctic soil microarthropod community. Ecography 23:299-306

Davidson EA, Janssens IA (2006) Temperature sensitivity of soil carbon decomposition and feedbacks to climate change. Nature 440:165-173

Díaz-Aguilar I, Quideau SA (2013) Trophic ecology of mesostigmatan and oribatid mites in harvested and control coniferous and deciduous stands of the boreal mixed wood forest determined using $15 \mathrm{~N}$ stable isotopes. Soil Biol Biochem 67:147-154

Dise NB (2009) Peatland response to global change. Science 326:810-811

Dollery R, Hodkinson ID, Jonsdottir IS (2006) Impact of warming and timing of snow melt on soil microarthropod assemblages associated with Dryas-dominated plant communities on Svalbard. Ecography 29:111-119

Dorrepaal E, Aerts R, Cornelissen JHC, Callaghan TV, van Logtestijn RSP (2004) Summer warming and increased winter snow cover affect Sphagnum fuscum growth, structure and production in a sub-arctic bog. Global Change Biol 10:93-104

Dorrepaal E, Aerts R, Cornelissen JHC, van Logtestijn RSP, Callaghan TV (2006) Sphagnum modifies climate-change impacts on subarctic vascular bog plants. Funct Ecol 20:31-41

Dorrepaal E, Toet S, van Logtestijn RSP, Swart E, van de Weg MJ, Callaghan TV, Aerts R (2009) Carbon respiration from subsurface peat accelerated by climate warming in the subarctic. Nature 460:616-679

Erdmann G, Volker O, Langel R, Scheu S, Maraun M (2007) The trophic structure of bark-living oribatid mite communities analysed with stable isotopes $(15 \mathrm{~N}, 13 \mathrm{C})$ indicates strong niche differentiation. Exp Appl Acarol 4:1-10

Farska J, Prejzkova K, Rusek J (2014a) Management intensity affects traits of soil microarthropod community in montane spruce forest. Appl Soil Ecol 75:71-79

Farska J, Prejzkova K, Stary J, Rusek J (2014b) Soil microarthropods in non-intervention montane spruce forest regenerating after barkbeetle outbreak. Ecol Res 29:1087-1096

Filser J (2002) The role of collembolan in carbon and nitrogen cycling in soil. Pedobiologia 46:234-245

Fischer B, Schatz H, Maraun M (2010) Community structure, trophic position and reproductive mode of soil and bark-living oribatid mites in an alpine grassland ecosystem. Exp Appl Acarol 52:221-237

Fischer B, Meyer E, Maraun M (2014) Positive correlation of trophic level and proportion of sexual taxa of oribatid mites (Acari: Oribatida) in alpine soil systems. Exp Appl Acarol 63:465-479

Gałka M, Szal M, Watson EJ, Galleo-Sala A, Amesbury MJ, Charman DJ, Roland TP, Turner TE, Swindles GT (2017) Vegetation succession, carbon accumulation and hydrological change in subarctic peatlands, Abisko, Northern Sweden. Permafrost Periglac 28:589-604

Garcia-Palacios P, Vandegehuchte ML, Shaw EA, Dam M, Post KH, Ramirez KS, Wall DH (2015) Are there links between responses of soil microbes and ecosystem functioning to elevated $\mathrm{CO}_{2}, \mathrm{~N}$ deposition and warming? A global perspective. Global Change Biol 21:1590-1600

Garnier E, Cortez J, Billès G, Navas M-L, Roumet C, Debussche M, Laurent G, Blanchard A, Aubry D, Bellmann A, Neill C, 
Toussaint J-P (2004) Plant functional markers capture ecosystem properties during secondary succession. Ecology 85:2630-2637

Hågvar S, Klanderud K (2009) Effects of simulated environmental change on alpine soil arthropods. Global Change Biol 15:2972-2980

Heemsbergen DA, Berg MP, Loreau M, van Hal JR, Faber JH, Verhoef HA (2004) Biodiversity effects on soil processes explained by interspecific functional dissimilarity. Science 306:1019-1020

Heijmans MM, Mauquoy D, van Geel B, Berendse F (2008) Long-term effects of climate change on vegetation and carbon dynamics in peat bogs. J Veg Sci 19:307-320

Hodkinson ID, Coulson SJ, Webb NR, Block W (1996) Can high arctic soil microarthropods survive eleveated summer temperatures? Funct Ecol 10:314-321

Hodkinson ID, Webb NR, Bale JS, Block W, Coulson SJ, Strathdee AT (1998) Global change and arctic ecosystems: conclusions and predictions from experiments with terrestrial invertebrates on Spitsbergen. Arct Alp Res 30:306-313

IPCC (2007) Climate change 2007: The physical science basis. contribution of Working Group I to the fourth assessment report of the intergovernmental panel on climate change. Cambridge University Press, Cambridge

IPCC (2014) Climate change 2014: synthesis report. Contribution of Working Groups I, II and III to the fifth assessment report of the intergovernmental panel on climate change. IPCC, Geneva

Kardol P, Reynolds WN, Norby RJ, Classen AT (2011) Climate change effects on soil microarthropod abundance and community structure. Appl Soil Ecol 47:37-44

Keuper F, Dorrepaal E, Van Bogedom BT, Aerts R, Van Longestijn RSP, Gallaghan T, Cornelissen JHC (2011) A race for space? How Sphagnum fuscum stabilizes vegetation composition during longterm climate manipulations. Global Change Biol 17:2162-2171

Keuper F, Van Bogedom BT, Dorrepaal E, Weedon JT, Van Hal J, Van Longestijn RSP, Aerts R (2012) A frozen feast: thawing permafrost increases plant-available nitrogen in subarctic peatlands. Global Change Biol 18:1998-2007

Koltz AM, Schmidt NM, Høye TT (2018) Differential arthropod responses to warming are altering the structure of Arctic communities. R Soc Open Sci. https://rsos.royalsocietypublishing.org/ content $/ 5 / 4 / 171503$

Krab E, Oorsprong H, Berg MP, Cornelissen JHC (2010) Turning northern peatlands upside down: disentangling microclimate and substrate quality effects on vertical distribution of Collembola. Funct Ecol 24:1362-1369

Krab EJ, Berg MP, Aerts R, Van Logtestijn RSP, Cornelissen JHC (2013) Vascular plant litter input in subarctic peat bogs changes Collembola diets and decomposition patterns. Soil Biol Biochem 63:106-115

Laakso J, Setälä H (1999) Sensitivity of primary production to changes in the architecture of belowground food webs. Oikos 87:57-64

Lang SI, Cornelissen JHC, Klahn T, Van Longestijn RSP, Broekman R, Schweikert W, Aerts R (2009) An experimental comparison of chemical traits and litter decomposition rates in a diverse range of subarctic bryophyte, lichen and vascular plant species. J Ecol 97:886-900

Lenoir L, Persson T, Begtsson J, Wallander H, Wirén A (2007) Bottom-up or top-down control in forest soil microcosms? Effects of soil fauna on fungal biomass and $\mathrm{C} / \mathrm{N}$ mineralization. Biol Fert Soils 43:281-294

Lindo Z (2015) Warming favors small-bodied organisms through enhanced reproduction and compositional shifts in belowground systems. Soil Biol Biochem 91:271-278

Lindo Z, Whitley J, Gonzales A (2012) Traits explain community disassembly and trophic contraction following experimental environmental change. Global Change Biol 18:2448-2457
Luoto M, Heikkinen RK, Carter TR (2004) Loss of palsa mires in Europe, and biological consequences. Environ Conserv 31:30-37

Makkonen M, Berg MP, Van Hal JR, Callaghan TV, Press MC, Aerts $\mathrm{R}$ (2011) Traits explain the responses of a sub-arctic Collembola community to climate manipulation. Soil Biol Biochem 43:377-384

Maraun M, Scheu S (2000) The structure of oribatid mite communities (Acari, Oribatida): patterns, mechanisms and implications for future research. Ecography 23:374-382

Maraun M, Visser S, Scheu S (1998) Oribatid mites enhance the recovery of the microbial community after a strong disturbance. Appl Soil Ecol 9:175-181

Marion GM, Henry GHR, Freckman DW, Johnstone J, Jones G, Jones MH, Lévesque E, Molau U, Mølgaard P, Parsons AN, Svoboda J, Virginia RA (1997) Open-top designs for manipulating field temperature in high-latitude ecosystems. Global Change Biol 3:20-32

McGill BJ, Enquist BJ, Weiher E, Westoby M (2006) Rebuilding community ecology from functional traits. Trends Ecol Evol $21: 178-185$

Moore JC, Walter DE, Hunt HW (1988) Arthropod regulation of microand mesobiota in below-ground detrital food webs. Annu Rev Entomol 33:419-439

Murvanidze M, Kvavadze E (2010) An inventory of Oribatid mites, the main decomposers in bogs of Colchic Lowland (Caucasus, Georgia). In: Sabelis M, Bruin J (eds) Trends in acarology. Springer, Dordrecht, pp 175-178

Nielsen UN, Ayres E, Wall DH, Bardgett RD (2011) Soil biodiversity and carbon cycling: a review and synthesis of studies examining diversity-function relationships. Eur J Soil Sci 62:105-116

Norton RA (1994) Evolutionary aspects of oribatid mite life histories and consequences for the origin of Astigmata. In: Houck MA (ed) Mites. Ecological and evolutionary analyses of life history patterns, Springer, Dordrecht, pp 99-135

O'Donnell JA, Jorgensen MD, Harden JW, McGuire AD, Kanevskiy MZ, Wickland KP (2012) The effects of permafrost thaw on soil hydrologic, thermal and carbon dynamics in an Alaskan peatland. Ecosystems 15:213-229

Palmer SC, Norton RA (1991) Taxonomic, geographic and seasonal distribution of thelytokous parthenogenesis in the Desmonomata (Acari: Oribatida). Exp Appl Acarol 12:67-81

Petchey OL, Belgrano A (2010) Body-size distributions and size-spectra: universal indicators of ecological status? Biol Lett 6:434-437

Renker C, Otto P, Schneider K, Zimdars B, Maraun M, Buscot F (2005) Oribatid Mites as potential vectors for soil microfungi: study of mite-associated fungal species. Microb Ecol 50:518

Roscher C, Schumacher J, Baade J, Wilcke W, Gleixner G, Weisser WW, Schmid B, Schulze E-D (2004) The role of biodiversity for element cycling and trophic interactions: an experimental approach in a grassland community. Basic Appl Ecol 5:107-121

Ruess L, Michelsen A, Schmidt IK, Jonasson S (1999) Simulated climate change affecting microorganisms, nematode density and biodiversity in subarctic soils. Plant Soil 212:63-73

Scheu S, Maraun M (2015) Oribatid mite communities on the bark of dead wood vary with log type, surrounding forest and regional factors. Appl Soil Ecol 89:102-112

Schneider K, Maraun M (2009) Top-down control of soil microarthropods - evidence from a laboratory experiment. Soil Biol Biochem 41:170-175

Schneider K, Renker K, Scheu S, Maraun M (2004) Feeding biology of oribatid mites: a mini review. Phytophaga 14:247-256

Schneider K (2005) Feeding biology and diversity of oribatid mites (Oribatida, Acari). Dissertation, University of Darmstadt

Sjursen H, Michelsen A, Holmstrup M (2005a) Effects of long-term soil warming and fertilisation on microarthropod abundances in three sub-arctic ecosystems. Appl Soil Ecol 30:148-161 
Sjursen H, Michelsen A, Holmstrup M (2005b) Effects of freeze-thaw cycles on microarthropods and nutrient availability in a sub-Arctic soil. Appl Soil Ecol 28:79-93

Smelansky IE (2006) Some population characteristics of oribatid mites in steppe habitats. Acarina 14:123-130

Staddon P, Lindo Z, Crittenden PD, Gilbert F, Gonzalez A (2010) Connectivity, non-random extinction, and ecosystem function in experimental metacommunities. Ecol Lett 13:543-552

Strack M (ed) (2008) Peatlands and climate change. International Peat Society, Jyväskylä

Treat CC, Jones MC, Camill P, Gallego-Sala A, Garneau M, Harden JW, Hugelius G, Klein ES, Kokfelt U, Kuhry P, Loisel J, Mathijssen PJH, O'Donnel JA, Oksanen PO, Ronkanen TM, Sannel ABK, Talbot J, Tarnocai CM, Väliranta M (2016) Effects of permafrost aggradation on peat properties as determined from a panarctic synthesis of plant macrofossils. J Geophys Res Biogeosci 121:78-94

Tsyganov AN, Aerts R, Cornelisson JHC, Beyenes L (2012) Sphagnum-dwelling testate amoebae in subarctic bogs are more sensitive to soil warming in the growing season than in winter: the results of eight-year field climate manipulations. Protist 163:400-414

Tullgren A (1918) Ein sehr einfacher Ausleseapparat für terricole Tierfaunen. Zeitschrift für angewandte Entomologie 4:149-150
Turnbull MS, Lindo Z (2015) Combined effects of abiotic factors on Collembola communities reveal precipitation may act as a disturbance. Soil Biol Biochem 82:36-43

Wall DH (2007) Global change tipping points: above-and belowground biotic interactions in a low diversity ecosystem. Philos Trans R Soc Lond B Biol Sci 362:2291-2306

Weigmann G (2006) Hornmilben (Oribatida). Goecke and Evers, Keltern

Wickings K, Grandy AS (2011) The oribatid mite Scheloribates moestus (Acari: Oribatida) alters litter chemistry and nutrient cycling during decomposition. Soil Biol Biochem 42:351-358

Wu T, Su F, Han H, Du Y, Yu C, Wan S (2014) Responses of soil microarthropods to warming and increased precipitation in a semiarid temperate steppe. Appl Soil Ecol 84:200-207

Yachi S, Loreau M (1999) Biodiversity and ecosystem productivity in a fluctuating environment: the insurance hypothesis. Proc Natl Acad Sci USA 96:1463-1468

Publisher's Note Springer Nature remains neutral with regard to jurisdictional claims in published maps and institutional affiliations. 